\title{
Barrennes: Jalan Penggenapan Janji Allah Bagi Keluarga Allah
}

\section{Barrenness: The fulfillment of God's Promise for God's family}

\author{
Yohanes Krismantyo Susanta ${ }^{1)^{*}}$ \\ 1) Dosen Sekolah Tinggi Agama Kristen Negeri Toraja \\ "Penulis korespondensi:yohanessusanta@gmail.com
}

\begin{abstract}
Abstrak
Kemandulan adalah tema umum dalam Alkitab terutama dalam Perjanjian Lama. Kemandulan merupakan persoalan serius bagi pasangan di dalam budaya yang menekankan pentingnya keturunan. Tulisan ini membuktikan bahwa kemandulan adalah karya Allah yang memiliki kehendak-Nya. Perspektif budaya tentang kemandulan akan dijelaskan dalam perseptif Perjanjian Lama. Tulisan ini menyatakan bahwa Allah dapat memakai kemandulan untuk meneguhkan iman keluarga Kristen kepada Allah. Allah juga dapat memakai kemandulan sebagai kesempatan bagi pasangan untuk melakukan adopsi anak. Allah dapat menggunakan kemandulan sebagai kesaksian bagi pasangan yang memiliki anak untuk menghargai anak-anak sebagai anugerah dari Allah.
\end{abstract}

Kata kunci: Barrenness, etika, Perjanjian Lama, anugerah, Allah, kesuburan, janda, sosial

Barrenness is a common theme in Scripture. Barrenness is a serious problem for couples in a culture that emphasizes the importance of descent. This writing proves that barrenness is the work of God having his will. The cultural perspective about infertility will be explained from the perspective of the Old Testament. This paper states that God can use barrenness to strengthen the Christian family's faith in God. God can also use barrenness as an opportunity for couples to adopt children. God can use barrenness as a witness for couples who have children to appreciate children as a gift from God.

Key Words: Barrenness, ethics, Old Testament, grace, God, fertility, widow, social

\section{Pendahuluan}

Kelahiran seorang anak disambut dengan sukacita. Berita kelahiran juga dapat dijumpai dalam warta gereja khususnya pada kolom kabar sukacita. Melalui peristiwa tersebut, setiap orang diajak untuk bersukacita bersama keluarga yang memperoleh anak. Kehadiran seorang anak dalam sebuah keluarga sangat dinantikan. Anak dianggap sebagai buah cinta dari pasangan suami-istri. Kegembiraan akan lebih dirasakan oleh pasangan suami-istri yang sudah lama tidak memiliki 
anak ketika sang bayi telah lahir. Tidak mengherankan jika sebagian besar pasangan yang telah menikah berharap bahwa mereka kelak akan memiliki keturunan, sama seperti keluarga-keluarga lainnya. Dalam kehidupan rumah tangga, keinginan memiliki anak dari pasangan suamiistri seringkali disertai dengan tuntutan dari orang tua atau pihak keluarga besar. Hal tersebut membuat pasangan yang belum memiliki keturunan dalam waktu yang cukup lama akan berusaha keras untuk segera memiliki anak. Berbagai usaha baik medis maupun tradisional, bahkan yang berhubungan dengan budaya serta tradisi keagamaan akan dilakukan. Hal tersebut penting sebab ketidakmampuan memiliki anak, pada sebagian besar keluarga termasuk di Indonesia, berpotensi besar untuk melahirkan masalah dalam kehidupan rumah tangga. Persoalan tersebut biasanya dalam bentuk perselingkuhan, perceraian atau keinginan memiliki istri lebih dari satu dengan alasan untuk memperoleh keturunan. Kisah ini adalah fakta yang ada di Indonesia dalam kebanyakan budaya di Indonesia. Kisah ini juga terdapat dalam banyak kisah dalam Alkitab terutama dalam Perjanjian Lama.

Tulisan ini mempertanyakan apakah kemandulan itu adalah anugerah atau masalah? Penulis ingin membuktikan bahwa kemandulan juga adalah anugerah Allah dan membuktikan bahwa "mitos" tentang kemandulan adalah masalah besar dalam keluarga adalah keliru. Penulis akan mengkaji dari Perjanjian Lama dan konteks budaya Indonesia mengenai keturunan dan kemandulan. Namun, tulisan ini berfokus pada konteks Perjanjian Lama dan implikasi praktis bagi keluarga Kristen terutama yang belum memiliki keturunan.

\section{Kehadiran Anak dalam Sebagian Konteks Budaya Indonesia}

Keluarga dan anak seringkali menjadi topik pembicaraan ketika dua sahabat lama bertemu kembali. Pembicaraan yang dilakukan sangat jarang membicarakan soal kesuksesan dan kekayaan. Hal tersebut sekaligus mengindikasikan betapa penting nilai anak dalam kehidupan seseorang atau keluarga yang melebihi nilai harta kekayaan yang dimiliki. ${ }^{1}$ Berdasarkan fenomena yang terjadi dalam konteks Indonesia tersebut, tampak bahwa masyarakat masih menganggap bahwa salah satu tujuan perkawinan adalah untuk memperoleh keturunan.

Kehadiran seorang anak (keturunan) merupakan harapan bagi hampir seluruh keluarga di Indonesia. Sebagai contoh, bagi suku Toraja, keturunan sangat penting karena dua hal mendasar. Pertama, tongkonan (rumah tradisional Toraja) menjadi tanda persekutuan dan persaudaraan

\footnotetext{
${ }^{1}$ Tjok Istri Putra Astiti, "Nilai Anak dalam Kehidupan Keluarga Orang Bali," dalam Bunga Rampai Sosiologi Keluarga, peny. T. O. Ihromi (Jakarta: Yayasan Obor Indonesia, 1999), 226.
} 
sesama turunan nenek. Oleh karena itu, jika tidak ada keturunan, tidak ada yang akan membangun tongkonan. Kedua, adanya pesta kematian (Rambu Solo'). Jika tidak ada keturunan, maka tidak ada yang akan melaksanakan upacara kematian. ${ }^{2}$ Selanjutnya, bagi masyarakat Batak Toba, tujuan hidup yang ideal dapat tercapai dengan menjalankan tiga misi budaya yaitu hagabeon (kebahagiaan), hamoraon (kekayaan) dan hasangapon (kehormatan). Sebagaimana dikatakan Harahap dan Siahaan,

Hagabeon sama artinya dengan bahagia dan sejahtera. Kebahagiaan yang dimaksudkan di sini adalah kebahagiaan dalam hal keturunan. Keturunan dipandang sebagai pemberi harapan hidup karena keturunan adalah kebahagiaan yang tidak ternilai bagi orangtua, keluarga dan kerabat. Hamoraon (kekayaan) adalah segala sesuatu yang dimiliki oleh seseorang di mana kekayaan ini diidentikkan dengan harta kekayaan dan anak. Hasangapon (kemuliaan \& kehormatan) merupakan kedudukan seseorang dalam lingkungan masyarakat. Untuk mencapai hasangapon seseorang harus terlebih dahulu berketurunan ( $g a b e$ ) dan memiliki kekayaan (mora). ${ }^{3}$

Dengan demikian, bagi masyarakat Batak Toba, kekayaan yang paling berharga dalam kehidupan mereka adalah keturunan, anak-cucu. ${ }^{4}$ Keluarga yang tidak memiliki keturunan dianggap tidak akan mencapai ketiga nilai tersebut.

Orang batak yang tidak memiliki keturunan seringkali disebut dengan perumpamaan, "nahabang so marimput, songgop so maringanan" (terbang seperti tidak kelihatan, mendarat seperti tidak punya tempat). ${ }^{5}$ Oleh karena itu, keluarga Batak Toba yang kesulitan memiliki anak biasanya akan melakukan berbagai cara untuk segera memiliki keturunan, mulai dari melakukan usaha medis (berobat ke dokter atau pengobatan alternatif) sampai melakukan ritual budaya yang diyakini dapat mempercepat kehamilan. Menurut penelitian Vergouwen, jika suatu keluarga tidak memiliki keturunan, maka suami dan kerabat lakilakinya akan mendatangi ayah dari pihak istri dan melalui upacara khusus memohon restu agar mertuanya memanjatkan doa supaya anak

2 T. O. Ihromi, Adat Perkawinan Toraja Sa'dan dan Tempatnya dalam Hukum Positif (Yogyakarta dan Jakarta: Gadjah Mada University Press dan Yayasan Obor Indonesia, 1981), 111-116.

${ }^{3}$ Basyral Hamidy Harahap dan Hotman Siahaan, Orientasi Nilai-nilai Budaya Batak Toba: Suatu Pendekatan Terhadap Perilaku Batak Toba dan Angkola-Mandailing (Jakarta: Sanggar Willem Iskandar, 1987), 57.

${ }^{4}$ Ibid., 136.

${ }^{5}$ Djapiter Tinambunan dan Rayendra L. Toruan, Orang Batak Kasar? Membangun Citra dan karakter (Jakarta: Elex Media Komputindo, 2010), 152. 
dan menantunya diberi karunia (keturunan). ${ }^{6}$ Dalam beberapa kasus, pasangan suami-istri Batak Toba yang kesulitan memiliki keturunan akan memutuskan untuk bercerai karena dianggap tidak berjodoh. Bahkan ada pula istri yang meminta suaminya untuk menikah lagi dengan perempuan lain untuk memperoleh anak agar garis keturunannya tidak punah (khususnya anak laki-laki). ${ }^{7}$ Hal tersebut sekali lagi menunjukkan bahwa keturunan merupakan idaman dan harapan bagi keluarga dalam masyarakat Batak Toba.

Pentingnya memiliki keturunan juga dijumpai dalam kehidupan masyarakat Bali. Keluarga yang tidak memiliki anak dianggap sebagai keluarga yang tidak beruntung. Sebutan yang muncul untuk menggambarkan kondisi tersebut adalah Nang Pocol dan Men Pocol atau Nang Bekung dan Men Bekung (pocol berarti rugi sedangkan bekung berarti mandul. Nang berarti ayahnya sedangkan Men berarti ibunya). ${ }^{8}$ Di dalam keluarga Bali, mempunyai anak sangat penting karena dianggap menjadi salah satu cara untuk membayar hutang kepada orangtua. Hal tersebut dipertegas dengan adanya pandangan bahwa seseorang baru mencapai tujuan hidup setelah memiliki cucu yang tampak dalam ungkapan yang berbunyi, "I cucu nyupat I kaki" (cucunya menyelamatkan kakeknya). ${ }^{9}$

Oleh karena itu, pasangan suami-istri yang belum memiliki anak akan berusaha memiliki anak (khususnya anak laki-laki), sebab anak laki-laki memiliki peran yang sangat penting dalam keluarga Bali. Anak laki-laki memegang tanggung jawab yang besar. Apabila keluarga tersebut hanya memiliki anak perempuan, maka anak perempuan tersebut akan diangkat menjadi sentana rajeg yaitu diberi status laki-laki melalui kawin nyeburin. ${ }^{10}$ Dalam keluarga Bali, anak laki-laki tertua atau termuda yang telah menikah akan menggantikan orang tua dalam melaksanakan segala kewajiban adat. Selain itu, anak laki-laki dan perempuan dalam masyarakat Bali juga dipercaya akan menjadi penyelamat orangtua yang telah meninggal untuk mencapai surga dengan melaksanakan upacara atma wedana untuk menyucikan arwah tersebut menuju kepada Tuhan atau lahir kembali ke dunia

${ }^{6}$ Jacob Cornelis Vergouwen, Masyarakat dan Hukum Adat Batak Toba (Yogyakarta: LkiS, 2004), xvi.

7 Jacob Cornelis Vergouwen, Masyarakat dan Hukum Adat Batak Toba (Yogyakarta: LkiS, 2004), 331-332.

${ }^{8}$ Astiti, 227.

${ }^{9}$ Ibid., 228-229.

${ }^{10}$ Kawin nyeburin adalah perkawinan di mana mempelai laki-laki masuk ke kerabat istri dengan berkedudukan sebagai perempuan dan mempelai perempuan tetap tinggal di kerabatnya sendiri dengan status laki-laki. Sebaliknya, bagi keluarga yang tidak memiliki anak, dapat mengangkat anak laki-laki dari keluarga lain (meras sentana). Lih. Astiti, 230. 
(reinkarnasi). ${ }^{11} \quad$ Dengan demikian, dapat dimengerti pentingnya keturunan (baik laki-laki maupun perempuan) bagi keluarga Bali. Oleh sebab itu, berbagai usaha akan dilakukan oleh pasangan suami-istri dan keluarga besarnya untuk memperoleh keturunan.

Berdasarkan fenomena tersebut, dapat ditarik kesimpulan bahwa bagi sebagian besar suku di Indonesia, keturunan memiliki arti penting dalam kehidupan perkawinan pasangan suami-istri. Kondisi serupa juga dapat dijumpai dalam beberapa kisah tokoh dalam Alkitab. Oleh sebab itu, setelah memperlihatkan pentingnya keturunan bagi sebagian besar suku di Indonesia, bagian selanjutnya dari tulisan ini akan dimulai dengan penelusuran beberapa teks-teks dan kisah Alkitab khususnya Perjanjian Lama yang mengindikasikan pentingnya keturunan bagi keluarga Israel. Hal tersebut bertujuan untuk menarik pelajaran dari kisah-kisah keluarga dalam Alkitab yang bergumul dengan persoalan tersebut. Pentingnya keturunan bagi orang Israel dapat dijumpai dalam beberapa kisah dalam Alkitab. Salah satunya dapat dilihat melalui dua bentuk perkawinan yang mengindikasikan pentingnya memiliki keturunan bagi keluarga dan masyarakat Israel.

\section{Keturunan dan Kemandulan dalam Perjanjian Lama}

Alkitab juga menunjukkan bahwa masyarakat pada zaman itu mempraktikkan bentuk perkawinan yang pada masa kini dianggap tidak lumrah yaitu perkawinan poligami dan levirat. Poligami dan levirat adalah dua bentuk perkawinan dalam Perjanjian Lama. Poligami merupakan perkawinan antara laki-laki dengan banyak istri. Alkitab mencatat beberapa contoh laki-laki atau suami yang memiliki istri lebih dari satu misalnya Lamekh, Abraham, Yakub, Daud, Salomo, dan lainlain. Perkawinan poligami juga membuka peluang bagi seorang laki-laki (suami) untuk berhubungan dengan budak perempuan demi melahirkan keturunan baginya seperti yang dijumpai dalam kisah Abraham, Sara dan Hagar, budaknya.

Bagi orang yang hidup pada zaman modern, kesan negatif dari bentuk perkawinan poligami akan langsung terlihat. Bentuk perkawinan demikian memang lahir dalam budaya yang mengedepankan dominasi laki-laki, termasuk dalam hidup berkeluarga. Akan tetapi perlu diingat bahwa bentuk perkawinan yang demikian adalah sesuai dengan konteks zaman pada waktu itu. Banyaknya istri berarti peluang untuk memiliki keturunan akan semakin besar. Meski demikian, hal lain yang perlu diingat adalah sesuai catatan de Vaux bentuk perkawinan poligami berpotensi besar menimbulkan konflik antaristri dalam satu rumah

${ }^{11}$ Astiti, 238. 
sebab istri yang mandul biasanya akan dihina dan direndahkan oleh istri yang lain (misalnya sikap Penina kepada Hana, atau Hagar kepada Sara). ${ }^{12}$ Sikap suami yang cenderung lebih memerhatikan seorang istri juga akan turut menimbulkan kecemburuan dari istri yang lain (Kejadian 29:30-31). ${ }^{13}$ Bentuk perkawinan poligami ternyata berpotensi besar untuk menghasilkan lebih banyak masalah dibandingkan bentuk perkawinan monogami. ${ }^{14}$

Bentuk perkawinan selanjutnya adalah perkawinan Levirat atau perkawinan ipar (Ulangan 25:-10). Istilah "levirat" berasal dari bahasa Latin levir, yang diterjemahkan ke dalam bahasa Ibrani yabam (ipar lakilaki). ${ }^{15}$ Di dalam hukum perkawinan levirat dikatakan apabila suami dari seorang istri meninggal tanpa keturunan, maka saudara laki-laki dari suami tersebut harus menikahi istri saudaranya untuk membangkitkan keturunan baginya. Di dalam Alkitab ada dua contoh perkawinan demikian yaitu dalam kisah Tamar (Kejadian 38:6-7) dan kisah Rut. ${ }^{16}$ Anak-anak hasil dari perkawinan tersebut akan menjadi ahli waris dari saudara laki-laki yang telah meninggal supaya "nama itu jangan terhapus dari antara orang Israel" (Ulangan 25:6). Apabila seorang laki-laki menolak untuk menikahi ipar perempuannya yang telah menjadi janda, ia akan dipermalukan di depan umum" (Ulangan 25:7-10; Rut 4:1-7). ${ }^{17}$ Dari kisah tersebut terlihat jelas betapa pentingnya keturunan bagi keluarga Israel. Dalam konteks zaman tersebut juga tampak jelas bahwa tujuan dari perkawinan, pertama-tama dipandang sebagai usaha untuk mendapatkan keturunan.

Dua bentuk perkawinan yang berlaku pada zaman tersebut secara tidak langsung mendukung sistem budaya yang menekankan keunggulan atau dominasi laki-laki dalam kehidupan keluarga Israel. Dari kedua bentuk perkawinan tersebut juga dapat disimpulkan bahwa

\footnotetext{
${ }^{12}$ Roland de Vaux, Ancient Israel Volume l: Social Institutions (New York: McGrawHill Book Company, 1965), 25.

${ }^{13}$ Ibid., 25.

${ }^{14}$ Hal tersebut tidak mengherankan sebab gagasan atau gambaran tentang perkawinan monogami tercermin di dalam kitab Kejadian melibatkan dua pribadi (seringkali dipahami sebagai dasar dari perkawinan monogami). Hal tersebut juga didukung oleh tulisan de Vaux sebelumnya yang mengatakan bahwa perkawinan monogami adalah bentuk umum yang berlaku di Israel.

15 de Vaux, 37.

${ }^{16}$ Kisah Rut dan Boas adalah salah satu contoh perkawinan levirat yang unik. Kerabat yang terdekat tidak bersedia menikahi Rut. Oleh karena itu Boas, sebagai kerabat terdekat berikutnya, bertindak sebagai kerabat penebus. Setelah membayar utang atas tanah pusaka Elimelekh, Boas mengambil Rut menjadi istrinya "untuk menegakkan nama orang yang telah mati itu di atas milik pusakanya. Demikianlah nama orang itu tidak akan lenyap dari antara saudara-saudaranya dan dari antara warga kota" (Rut 4:10). Lih. Ensiklopedi Fakta Alkitab, s.v. "Pernikahan dan Perceraian".

17 Ibid.
} 
tujuan perkawinan bagi orang Israel adalah untuk memiliki anak (dalam jumlah yang besar) demi meneruskan garis keturunan keluarga.

Keturunan Sebagai Penjamin Masa Depan Keluarga Israel

Harapan untuk mempunyai banyak keturunan seolah menjadi prioritas dalam perencanaan suami-istri dan keluarga besar di Israel. Hal tersebut salah satunya dapat dijumpai dalam kisah peminangan Ribka untuk menjadi istri Ishak. Sebelum Ribka pergi ke rumah mertuanya untuk menjadi istri dari Ishak, juru bicara keluarga mengucapkan sepenggal kalimat yang berisi harapan, "Saudara kami, moga-moga engkau menjadi beribu-ribu laksa, dan moga-moga keturunanmu menduduki kota-kota musuhnya" (Kejadian 24:60). Ungkapan yang serupa juga diberikan kepada Rut sebelum pernikahannya dengan Boas (Rut 4:11-12). ${ }^{18}$ Ungkapan tersebut secara sederhana memperlihatkan bahwa keturunan menjadi penting bagi masyarakat Israel pada masa itu.

Selain itu, bagi orang Israel, kehidupan adalah sesuatu yang dipandang sakral sekaligus pemberian Allah. Hal yang menarik dalam Mazmur 127:3 dikatakan bahwa anak bukan hanya pemberian Tuhan melainkan milik pusaka Tuhan. ${ }^{19}$ Dengan demikian, secara tidak langsung, memiliki keturunan berarti selaras dengan kehendak Allah. Memiliki keturunan berarti menyambung kehidupan keluarga dan kehidupan tersebut adalah anugerah dari Allah. Memiliki keturunan berarti menjamin kehidupan keluarga. Bahkan menjamin kehidupan bangsa.

Menurut Perdue, tidak mengherankan jika reproduksi merupakan salah satu fungsi penting dari keluarga (Kejadian 1:28;9:1) dan perempuan memiliki peran yang sangat penting dalam menghasilkan banyak keturunan (Kejadian 24:60). ${ }^{20}$ Keturunan yang dihasilkan akan menyambung nama nenek moyang sekaligus memelihara tradisi keluarga serta menjadi penjamin kehidupan umat secara keseluruhan.

Kemandulan Sebagai Hukuman ataukah Jalan Penggenapan Janji TUHAN?

Apabila keturunan dipandang sebagai harapan bagi keluarga dan masyarakat Israel, maka tentunya kemandulan menjadi persoalan serius bagi setiap keluarga Israel. Itu sebabnya, di dalam Alkitab dijumpai kisah-kisah tentang keluarga mandul yang berusaha untuk keluar dari

${ }^{18}$ J. I. Packer, Merril C. Tenney, William White, Jr, Ensiklopedi Fakta Alkitab s.v.

"Kelahiran dan Masa Bayi".

${ }^{19}$ Y. M. Seto Marsunu, "Pendidikan Iman Anak dalam Perjanjian Lama dan Tradisi Yahudi," Wacana Biblika Vol. 13 No. 4 (Oktober-Desember 2013): 148.

${ }^{20}$ Leo G. Perdue, "The Israelite and Early Jewish Family: Summary and Conclusions," dalam Families in Ancient Israel, peny. Don S. Browning dan Ian S. Evison (Louisville: Westminster John Knox Press, 1997), 170. 
situasi tersebut. Salah satu kisah yang terkenal dalam Alkitab adalah kisah Abraham, Sara dan Hagar. Alkitab menceritakan tentang Sara yang mandul, yang memberikan Hagar, budaknya, kepada Abraham untuk membangkitkan keturunan baginya meskipun hal tersebut tidak sesuai dengan rencana Tuhan (Kejadian 16:1-16).

Kemandulan ibarat musuh bagi setiap keluarga Israel. Kemandulan dipandang sebagai aib keluarga. Dalam konteks zaman itu (ilmu kedokteran belum maju), perempuan dianggap sebagai penyebab ketidakmampuan untuk memiliki keturunan. Gambaran tentang istri mandul adalah salah satu dari gambaran kesedihan dan rasa tertolak yang paling kuat dalam Alkitab. ${ }^{21}$

Seorang istri yang tidak dapat mempunyai anak sering kali menjadi objek ejekan karena ketidakmampuannya mengandung dan melahirkan anak, khususnya anak laki-laki (Kejadian 30:1-2, 23; 1 Samuel 1:6-10).22 Dalam keadaan demikian, kita dapat memperkirakan bahwa dari sudut pandang sosial, perempuan akan merasa malu sedangkan dari sudut pandang psikis, kemungkinan besar perempuan atau istri akan sangat tertekan. Belum lagi dari sudut pandang keagamaan atau kerohanian, ia mungkin merasa bersalah karena berpikir bahwa ketidakmampuannya menghasilkan keturunan adalah karena dosa yang ia perbuat di masa lalu.

Kondisi tersebut dapat dijumpai dalam kisah Hana, Ibu Samuel. Ia merasa malu dan sakit hati karena memperoleh penghinaan dari Penina, istri kedua suaminya, Elkana (1 Samuel 1:6-8). Meskipun bukan hanya istri yang menanggung beban berat tersebut (suami juga merasakannya), ${ }^{23}$ akan tetapi dalam konteks zaman itu, posisi laki-laki sedikit lebih menguntungkan sebab ia tidak dipersalahkan oleh masyarakat serta dapat mencari solusi dengan cara menikah lagi (poligami) atau berhubungan dengan budak perempuan untuk memperoleh keturunan.

Perjanjian Lama memang memperlihatkan bahwa sistem atau kondisi masyarakat pada zaman itu memandang tujuan utama dari perkawinan adalah untuk membangkitkan keturunan. Dalam Perjanjian Lama tertuang suatu gagasan bahwa Allah menciptakan manusia untuk bertambah dan beranakcucu dan menjadi kontras ketika berbicara kemandulan sebagai kutuk dan hukuman. Joel S. Baden menafsirkan

\footnotetext{
${ }^{21}$ Dictionary of Biblical Imagery, s.v. "Barrenness".

${ }^{22}$ Maura A. Ryan, Ethics and Economics of Assisted Reproduction (Washington: Georgetown University Press, 2003), 52.

${ }^{23}$ Ketika Rahel yang putus asa karena belum memiliki anak mengatakan, "Berikanlah kepadaku anak; kalau tidak, aku akan mati" (Kej. 30:1). Yakub memberikan jawaban yang tidak kalah sengit, "Akukah pengganti Allah, yang telah menghalangi engkau mengandung?” (Kej. 30:2).
} 
bahwa kemandulan adalah bagian dalam kehidupan bangsa Israel dan semua bangsa. Dalam Ulangan 7:14, "Engkau akan diberkati lebih dari segala bangsa: tidak akan ada laki-laki atau perempuan yang mandul di antaramu, ataupun di antara hewanmu." Secara umum kemandulan adalah hal yang dialami secara normal oleh bangsa Israel dan semua bangsa. ${ }^{24}$ Kemandulan bukanlah sebuah hukuman namun kemandulan dijadikan Allah menjadi berkat untuk beroleh keturunan.

Courtney Reissig menjelaskan kemandulan dalam Alkitab sebagai berikut.

Kemandulan adalah tema umum dalam Alkitab. Terkadang digunakan untuk menyoroti penghakiman Allah atas orang-orang yang memberontak (Ayub 15:34). Terkadang digunakan untuk menunjukkan kemuliaan Allah dalam membuka rahim perempuan yang tidak pernah diimpikan sebelumnya (Kejadian 25:21, Hakim 13:3). Terlepas dari bagaimana kemandulan digunakan, kemandulan membawa situasi rasa malu sama di manapun kemandulan digambarkan. Jika benih yang dijanjikan itu seharusnya masuk melalui perempuan itu, perempuan mandul itu akhirnya melahirkan anak yang diharapkan selama ini. Selain itu, keberhasilan dalam bentuk kehadiran anak dipandang sebagai tanda kemurahan Allah (Keluaran 23:26). Tanpa buah rahim Anda, Anda tidak hanya dilihat sebagai orang berdosa yang dikutuk, tetapi juga wanita tanpa tujuan. Tetapi salah satu pesan menyeluruh tentang kemandulan dalam Alkitab adalah bahwa Allah tidak terkejut karenanya. ${ }^{25}$

Tulisan di atas beranggapan bahwa kemandulan dapat menunjukkan hukuman bagi yang memberontak kepda Allah dan dapat menjadi berkat sebagai tanda kemurahan Allah (God's favor) dan dalam persepsi Allah tidak terkejut oleh karena kemandulan itu sendiri.

Persoalan kemandulan yang dianggap sebagai hukuman dari Allah, Phyllis Trible menanggapinya sebagai berkat dalam bukunya yang berjudul God and the Rhetoric of Sexuality mengangkat tiga kisah yaitu Sara di istana Abimelekh; Lea dan Rahel, serta Hana untuk memperlihatkan bahwa Allah digambarkan sebagai Sang empunya rahim (kandungan). ${ }^{26}$ Allah melindungi Sara dengan cara menutup kandungan setiap perempuan dalam istana Abimelekh sebagai bentuk hukuman karena ia mengambil istri Abraham - walaupun atas persetujuan Abraham sendiri - (Kejadian 20:1-18). Dalam kisah lain diceritakan bahwa Allah sendirilah

${ }^{24}$ Joel S. Baden, "The Nature of Barrenness in the Hebrew Bible," in Disability Studies And Biblical Literature ed. Candida R. Moss, Jeremy Schipper (New York: Palgrave Macmillan, 2011), 14.

${ }^{25}$ Courtney Reissig, "A Barren Woman's Home is Not Homeless," diakses 10 September 2017, https://cbmw.org/topics/barrenness/a-barren-womans-home/ Penulis menerjemahkan bagian artikel di atas.

${ }^{26}$ Phyllis Trible, God and the Rhetoric of Sexuality (Philadelphia: Fortress Press, 1983), 34. 
yang membuka kandungan Lea sebagai bentuk berkatnya bagi Lea, serta Allah juga yang mengingat dan membuka kandungan Rahel serta Hana setelah sebelumnya menutup kandungan tersebut (1 Samuel 1:1-20). Apabila dalam kisah Sara dan Abimelekh, Allah menutup kandungan sebagai bentuk hukuman, maka tidak ada penjelasan mengapa Allah menutup kandungan Rahel dan Hana, lalu mengingat dan membuka kandungan tersebut. Tidak disebutkan pula bahwa tindakan tersebut adalah hukuman atas dosa perempuan-perempuan tersebut di masa lalu. Hal itu menjadi kedaulatan dan misteri Allah. ${ }^{27}$ Kisah tersebut memperlihatkan bahwa kontrol atas rahim perempuan bukan berada pada perempuan atau sang suami, tetapi hanya Allah yang berkuasa membuka dan menutup kandungan dalam penghukuman, berkat dan misteri. ${ }^{28}$ Dengan demikian, kecuali kisah Abraham dan Sara di istana Abimelekh, dapat disimpulkan bahwa kemandulan tidak identik dengan hukuman Allah. Kisah-kisah tentang perempuan mandul dalam Alkitab diangkat untuk menekankan bahwa Allah sendiri yang berkuasa mengatur siapa yang dapat mengandung, kapan dan bagaimana mereka dapat mengandung. Kemandulan tidak terkait dengan hukuman Allah atas pasangan suami-istri tersebut.

\section{Implikasi Praktis Bagi Keluarga Kristen Masa Kini}

\section{Kemandulan adalah Jalan Penggenapan Janji Anugerah-Nya}

Pemahaman budaya tentang memiliki keturunan dalam sebagian budaya Indonesia telah mengubah orientasi tujuan Allah membentuk keluarga sebagai bagian keluarga Allah menjadi tujuan umum dan strata sosial. Dalam persepsi manusia kemandulan adalah bencana, aib serta hukuman Allah, namun Allah memiliki rencana untuk menggenapi janjiNya bagi manusia. Melalui kemandulan, Allah menyatakan mukjizatnya dengan membuka rahim perempuan untuk tujuan-Nya.

Melalui pemahaman di atas, keluarga-keluarga Kristen disadarkan bahwa anak bukanlah milik keluarga secara eksklusif, namun menjadi milik Allah dalam persekutuan keluarga Allah. Kehadiran anak dalam sebuah keluarga semata-mata adalah pemberian atau anugerah Tuhan. Apabila orang Kristen sungguh-sungguh menyadari anak sebagai pemberian yang hanya diperoleh karena kemurahan Tuhan, maka belum atau tidak adanya anak dalam sebuah keluarga seharusnya tidak dipandang sebagai persoalan yang sangat besar. Ketika anak-anak belum hadir dalam sebuah keluarga, hal tersebut kemungkinan karena Tuhan belum berkenan memberikan anugerah-Nya berupa keturunan sehingga

\footnotetext{
27 Trible, 35

${ }^{28}$ Ibid., 35.
} 
manusia hanya dapat berusaha, namun tidak perlu sampai memaksakannya. ${ }^{29}$

Bagi mereka yang pada akhirnya tidak dikaruniai anak, kemungkinan Allah bermaksud supaya mereka dapat menggunakan waktu dan kebebasannya untuk melayani atau bekerja dengan maksimal- sesuatu yang mungkin tidak dapat dikerjakan oleh mereka yang mempunyai anak. ${ }^{30}$ Selain itu, kemandulan juga dapat digunakan sebagai sebuah kesempatan untuk mengadopsi, sebuah anugerah baik bagi anak yang akan diadopsi maupun bagi orang tua yang mau mengadopsi. Akan tetapi adopsi seharusnya tidak dimaknai hanya sekadar solusi bagi yang tidak memiliki anak, sebab jika demikian, akan timbul degradasi nilai dari adopsi: adopsi merupakan sebuah pelarian. Adopsi harus dimaknai pula sebagai komitmen pasangan suami-istri di hadapan Allah untuk menjadi orang tua. Setiap keluarga dapat diajak untuk memperhatikan kehidupan orang lain dengan cara mengangkat anak, sebab ada banyak anak di dunia ini yang tidak memiliki orangtua. ${ }^{31}$ Tindakan mengangkat anak bukanlah sebagai pancingan untuk memperoleh keturunan - sebagaimana yang dipahami dan dipercaya oleh sebagian orang saat ini - melainkan sebagai salah satu wujud dari penghargaan dan ungkapan syukur terhadap kehidupan yang diberikan Tuhan. Dengan mengangkat anak, maka pasangan suami-istri tersebut secara sadar mengambil sebuah tanggung jawab sebagai orangtua, (meskipun anak tersebut adalah anak angkat) sekaligus menjalankan mandat dari Tuhan.

Hidup di tengah masyarat Indonesia yang cenderung menuntut dan mengukur salah satu nilai keberhasilan keluarga adalah dengan kehadiran anak memang menjadi tantangan, khususnya bagi setiap keluarga yang belum memiliki keturunan meskipun telah menikah cukup lama. Ketiadaan anak dalam keluarga seringkali dianggap oleh sebagian orang sebagai hal yang kurang wajar bahkan seringkali menjadi bahan pembicaraan(entah secara sengaja atau tidak). Justru di sini gereja memiliki peran besar untuk meluruskan pemahaman yang keliru tentang keturunan dan kemandulan. Gereja perlu memberikan pemahaman yang benar sehingga pasangan yang belum memilki anak tidak perlu merasa malu di dalam komunitasnya sendiri dan memikirkan solusi instan

\footnotetext{
${ }^{29}$ Pandangan ini tidak bermaksud untuk menyederhanakan masalah kemandulan tetapi penulis memandangnya dari perspektif anugerah Allah.

30 Ashmon Scott and Robert W. Weise, "Give Me Children, or I Will Die:

Procreation Is God's Work," Concordia Journal (Oktober 1998): 344-345.

${ }^{31}$ Langkah alternatif ini perlu diperkenalkan sebab entah disadari atau tidak, keinginan memperoleh anak seringkali dipaksakan untuk memenuhi ego, melayani kepentingan diri sendiri. Tidak heran jika anak seringkali dianggap sebagai aset (bukan sebagai pribadi) untuk kehidupan di masa mendatang.
} 
seperti bercerai atau menikah lagi. Dengan memberikan pemahaman yang tepat, maka jemaat, khususnya pasangan suami-istri yang belum memiliki anak tidak perlu merasa malu, apalagi berpikir bahwa kemandulan adalah hukuman dari Tuhan.

Keturunan adalah Anugerah Tuhan untuk Penggenapan Janji-Nya

Hal yang sama juga berlaku bagi keluarga yang telah diberikan anugerah berupa keturunan. Ketika keluarga tersebut memiliki anak, hendaknya mereka tidak menganggapnya sebagai hal yang lumrah dan wajar (taken for granted) atau sebaliknya, merasa bangga karena memiliki keturunan. Keluarga tersebut perlu mengingat kembali bahwa anakanak tersebut hadir dalam keluarga mereka karena Tuhan mau, berkenan, dan berkehendak atas hal tersebut. Tuhan memberikan anugerah-Nya berupa keturunan. Itu sebabnya keluarga yang memiliki anak juga tidak dapat berlaku sewenang-wenang, apalagi sampai menelantarkan anak mereka. Sebab anak-anak tersebut bukanlah milik mereka sendiri, anak-anak tersebut adalah milik Tuhan, milik pusaka Tuhan.

Perkawinan pada masa kini seharusnya tidak didasari dengan tujuan untuk mendapatkan anak. Keinginan tersebut memang tidak keliru dan berdosa, tetapi seharusnya tidak menjadi tujuan utama. Tujuan pernikahan harus dipahami dalam kedewasan iman bahwa setiap suamiistri dipanggil untuk menikmati kebersamaan secara eksklusif dalam rangka perjanjian -dengan Allah sebagai inisiatornya-melalui cinta di antara pasangan suami-istri tersebut. ${ }^{32}$ Perkawinan yang dikaruniakan anak yang merupakan milik Allah yang bertujuan untuk menggenapi janji dan kehendak-Nya di muka bumi.

\section{Penutup}

Persepsi dan harapan untuk memiliki keturunan masih dianggap sebagai hal yang sangat penting bagi masyarakat masa kini. Itu sebabnya ketidakhadiran seorang anak akan menjadi persoalan, khususnya bagi pasangan suami-istri yang telah lama menikah. Dengan demikian, kemandulan menjadi kabar buruk yang tidak diharapkan dan tidak ingin didengar oleh setiap pasangan suami-istri. Berhadapan dengan persoalan tersebut, keluarga perlu diajak untuk membingkai ulang (reframing)

32 Meskipun dalam Perjanjian Lama, unsur cinta seringkali dianggap bukan faktor utama bagi pasangan yang akan menikah (sebab pasangan tersebut biasanya dijodohkan). Akan tetapi beberapa bagian Alkitab seperti kitab Kidung Agung memberikan sudut pandang lain tentang ungkapan cinta sebagai fondasi yang memperkuat ikatan pernikahan seseorang, bukan semata-mata untuk memperoleh keturunan. Lih. Albertus Purnomo, "Antara Kontrak dan Cinta: Perkawinan dalam Perjanjian Lama,” Wacana Biblika Vol. 13 No. 1 (Januari-Maret 2013): 10. 
pemahaman yang selama ini mereka pegang. Memiliki anak bukanlah tujuan utama dalam perkawinan. Perkawinan adalah wadah yang disediakan oleh Allah bagi laki-laki dan perempuan untuk menikmati kebersamaan secara eksklusif. Kehadiran anak hanyalah salah satu dari aspek perkawinan tersebut dan kehadirannya merupakan berkat sekaligus anugerah dari Allah. Keluarga yang diberikan anugerah tersebut sudah sepatutnya mengucap syukur dan memandangnya sebagai tanggung jawab yang harus dilaksanakan dengan penuh perhatian. Sebaliknya, keluarga yang belum memiliki anak memahami peristiwa ini sebagai jalan penggenapan janji dan kehendak-Nya dalam kehidupan keluarga Kristen. Dalam perspektif Allah kemandulan adalah sarana dan bukan substansi manusia itu sendiri. Allah memandang manusia sebagai rupa Allah sendiri yang lebih berharga untuk menggenapi rencana-Nya dibandingkan melihat kemandulan sebagai hukuman bagi umat-Nya. Oleh karena itu, peritiwa ini dijadikan jalan untuk mendekati Tuhan dan mengenal maksud dan kehendak-Nya bagi keluarga-keluarga Kristen pada masa kini.

\section{Kepustakaan}

Browning, Don S. dan Ian S. Evison Families in Ancient Israel. Louisville: Westminster John Knox Press, 1997.

Campbell, Ken M. Marriage and Family in the Biblical World. Louisville: InterVarsity Press, 2003.

de Vaux, Roland. Ancient Israel Volume 1: Social Institutions. New York: McGraw-Hill Book Company, 1965.

Harahap, Basyral Hamidy dan Hotman Siahaan. Orientasi Nilai-nilai Budaya Batak Toba: Suatu Pendekatan Terhadap Perilaku Batak Toba dan AngkolaMandailing. Jakarta: Sanggar Willem Iskandar, 1987.

Ihromi, T. O. Adat Perkawinan Toraja Sa'dan dan Tempatnya dalam Hukum Positif. Yogyakarta dan Jakarta: Gadjah Mada University Press dan Yayasan Obor Indonesia, 1981.

Ihromi, T. O. Bunga Rampai Sosiologi Keluarga. Jakarta: Yayasan Obor Indonesia, 1999.

Marsunu, Y. M. Seto. "Pendidikan Iman Anak dalam Perjanjian Lama dan Tradisi Yahudi." Wacana Biblika 13, No. 4 (Oktober-Desember 2013): 147-158.

Moss, Candida R., Jeremy Schipper (ed.). Disability Studies And Biblical Literature. New York: Palgrave Macmillan, 2011.

Packer, J. I., Merrill C. Tenney, William White Jr, peny. Ensiklopedi Fakta Alkitab 2. Terj. Johan C. Pandelaki dan Sutrisno. Malang: Gandum Mas, 2001. 
Ensiklopedi Fakta Alkitab 2. Terj. Johan C. Pandelaki dan Sutrisno. Malang: Gandum Mas, 2001.

Purnomo, Albertus. "Antara Kontrak dan Cinta: Perkawinan dalam Perjanjian Lama.” Wacana Biblika 13 No. 1 (Januari-Maret 2013): 3-10.

Reissig, Courtney. "A Barren Woman's Home is Not Homeless." Diakses 10 September 2017. https://cbmw.org/topics/barrenness/a-barrenwomans-home/

Ryan, Maura A. Ethics and Economics of Assisted Reproduction. Washington: Georgetown University Press, 2003.

Ryken, Leland, Jim Wilhoit, dan Tremper Longman III, peny. Dictionary of Biblical Imagery. Downers Grove: InterVarsity Press, 2000.

Scott, Ashmon and Robert W. Weise. "Give Me Children, or I Will Die: aProcreation Is God's Work." Concordia Journal 24/4 (Oktober 1998): 337-345.

Spronk, Klaas. "The Ancestors in the Religion of Ancient Israel and in Christian Theology: A Contribution to the Intercultural Reading of the Bible." Gema Teologi 34 No. 1 (April 2010): 24-34.

Tinambunan, Djapiter dan Rayendra L. Toruan. Orang Batak Kasar? Membangun Citra dan Karakter. Jakarta: Elex Media Komputindo, 2010.

Trible, Phyllis. God and the Rhetoric of Sexuality, edisi ketiga. Philadelphia: Fortress Press, 1983.

Vergouwen, Jacob Cornelis. Masyarakat dan Hukum Adat Batak Toba. Yogyakarta: LkiS, 2004. 